


\title{
The Constitutional Court in the System of Public Authorities: A Doctrinal Approach
}

\author{
DOI: https://doi.org/10.46398/cuestpol.3969.19
}

\author{
Elena V. Vinogradova * \\ Ekaterina S. Ganicheva ** \\ Kasa Ilda *** \\ Badma V. Sangadzhiev **** \\ Natella A. Sinyaeva $* * * * *$
}

\section{Abstract}

The article examines the place and role of the Constitutional Court in the system of public powers in the doctrinal understanding of the concept of human rights and constitutionalism. The Constitution of the Russian Federation establishes the basic constitutional and legal principles that are fundamental to substantive and procedural law. Judicial constitutional review, as the experience of European countries shows, is the most effective in protecting the Constitution. The principles of law applied to the doctrinal assessment of the place and role of the Constitutional Court in the system of public powers constitute a rather dynamic legal concept. The methodology is based on the legal system, public relations, and the political-state course, which, like all fundamental ideas, change, affect legal awareness and establish new requirements for legal regulation and the formation of an appropriate mechanism. The article concludes that the most important condition for the implementation of the prerogatives of the judiciary to administer justice in the consideration and resolution of specific cases, with emphasis on the study and evaluation of evidence. It is the evidence that serves as the basis of information for the court's findings in the case.

* Institute of State and Law of the Russian Academy of Sciences, Moscow, Russia. ORCID ID: https:// orcid.org/oooo-0002-3568-9042. Email: evsfrf@gmail.com

** Institute of Legislation and Comparative Law under the Government of the Russian Federation, Moscow, Russia. ORCID ID: https://orcid.org/oooo-ooo3-3597-9928. Email: ekaterina.ganitcheva@ gmail.com

*** Peoples' Friendship University of Russia (RUDN University), Moscow, Russia. ORCID ID: https:// orcid.org/oooo-ooo3-3805-7371. Email: kasa_i@pfur.ru

**** Peoples' Friendship University of Russia (RUDN University), Moscow, Russia. ORCID ID: https:// orcid.org/oooo-0001-8317-0117. Email: sangadzhiev-bv@rudn.ru

***** PhD of law, Associate professor, Military University of the Ministry of Defense of the Russian Federation, Moscow, Russia. ORCID ID: https://orcid.org/oooo-0003-4217-8467. Email: Natella. Sinyaeva@gmail.com 
Keywords: constitutional court; public authorities; procedural law; doctrinal approach; Russia federation.

\section{El Tribunal Constitucional en el Sistema de Poderes Públicos: Un enfoque doctrinal}

\section{Resumen}

El artículo examina el lugar y el papel del Tribunal Constitucional en el sistema de poderes públicos en la comprensión doctrinal del concepto de derechos humanos y constitucionalismo. La Constitución de la Federación de Rusia establece los principios constitucionales y legales básicos que son fundamentales para el derecho sustantivo y procesal. La revisión constitucional judicial, como muestra la experiencia de los países europeos, es la más eficaz en la protección de la Constitución. Los principios de derecho aplicados a la valoración doctrinal del lugar y papel del Tribunal Constitucional en el sistema de poderes públicos constituyen un concepto jurídico bastante dinámico. La metodología se basa en el ordenamiento jurídico, las relaciones públicas y el rumbo político-estatal, que, como todas las ideas fundamentales, cambian, afectan la conciencia jurídica y establecen nuevos requisitos para la regulación legal y la formación de un mecanismo adecuado. El artículo concluye que la condición más importante para la implementación de las prerrogativas del poder judicial para administrar justicia en la consideración y resolución de casos específicos, con énfasis en el estudio y valoración de las pruebas. Es la evidencia que sirve como base de información para las conclusiones del tribunal en el caso.

Palabras clave: tribunal constitucional; autoridades públicas; derecho procesal; enfoque doctrinal; federación rusa.

\section{Introduction}

The Constitution is the basic law (system of laws) of the state, which has the highest legal force. It establishes the foundations of social order and government, the relationship between the state and the individual, the rights and freedoms of man and citizen, and the fundamental principles of organization and activity of state authorities (Vitruk, 2013). The supreme legal force of the constitution means that all other laws, other acts, and law enforcement practices must comply with it, otherwise, they are invalid. If the norms of the constitution are not observed, then the basic law will remain a dead letter, its norms will only be declarative. To avoid 
Elena V. Vinogradova, Ekaterina S. Ganicheva, Kasa Ilda, Badma V. Sangadzhiev y Natella A. Sinyaeva

a contradiction between the legal and actual constitution, a special control over its observance is necessary, which is constitutional control (Kozlova and Kutafin, 2012).

The most important condition for the implementation of the prerogatives of the judiciary to administer justice in the consideration and resolution of specific cases is the study and assessment of the evidence. It is the evidence that serves as the information basis for the court's conclusions in the case. However, one of the means of obtaining evidence is expertise, which is generally understood as the study of any issues by experts, the solution of which requires special knowledge. Constitutional court proceedings are no exception in this sense, which, according to part 2 of Article 118 of the Constitution of the Russian Federation, is one of the forms of exercising judicial power. Since the Constitutional Court of the Russian Federation considers and resolves only questions of law, the knowledge that may potentially be required for the resolution of cases referred to its competence is primarily legal.

\section{Methods}

At present, there are ongoing discussions about the legal nature of the Constitutional Court, the future of constitutional legal proceedings, procedural legislation, and procedural law. Many modern Russian scholars are engaged in the theory of procedural law and the theory of constitutional proceedings: A. Pavlushina, O.E. Soldatova, V.N. Balandin, and others. Moreover, this legal category is interdisciplinary. However, it is treated ambiguously in the theory of state and law and is not recognized by all scholars. Each branch of substantive law must have its procedural continuation. Substantive and procedural law are legal communities in the system of law, despite all the differences that have a close relationship with each other. For example, S.S. Alekseev (1994), V.N. Balandin, A.V. Vasilev (2008), V.M. Gorshenev (1985), etc. wrote about the place and role of constitutionalism in the development of the state.

The doctrine of a normative legal act as a source of law is a kind of legal doctrine. It allows formulating the main legal concepts and categories, as well as focusing on the implementation of research tasks aimed at the theoretical and legal justification of the features of a normative legal act. The greatest attention in the modern theory of law and the theory of branches of law is paid to the relationship between the source and the form of law. Legal theorists and scholars in the field of constitutional law pay attention to the multiplicity of the concept of the source of constitutional law. The Constitution of the Russian Federation establishes the basic constitutional and legal principles that are fundamental for both substantive and procedural 
law. The principle as the initial idea, the provision, should be uniform in its content for both substantive and procedural law. Consequently, the principle enshrined in the Constitution should be transferred to other legal acts without modification and have a uniform interpretation to exclude discrepancies. Principles are a dynamic legal phenomenon. Their formation takes quite a long time, they depend on the specific state-political situation, the requirements that establish the existing social relations and legal practice. The principles may not be clearly expressed in the legislation and may be found in various parts of it. Optimally, they should be enshrined in the constitution. The principles may change according to the requirements of the time, changes in the legal system, and legislation.

\section{Results}

Constitutions and charters of the subjects of the Russian Federation as a source and form of the constitutional law of the Russian Federation are based on the doctrine that reveals three main characteristics. The first main characteristic concerns the predetermination of the origin, objective necessity, and conditionality of the constitutions and charters of the subjects of the Russian Federation. It is this characteristic that reflects the qualities of the constitution, the charter of the subject of the Russian Federation as a source of law. In this context, it is important to substantiate the genesis of the origin, concept, and legal nature of the constitution, the charter of the subject of the Russian Federation as a source of law. The legal nature, in turn, is revealed through such key categories as the properties and functions of constitutions and charters of the subjects of the Russian Federation, reflecting the unique purpose of this type of normative legal acts (Ershov, 2018).

The second main characteristic reveals the features and place of constitutions and charters of the subjects of the Russian Federation as a form of law. In this context, it is important to determine the correlation of constitutions and charters of the subjects of the Russian Federation with other normative legal acts in a hierarchically organized legal system of the Russian Federation and the subjects of the Russian Federation.

The third main characteristic is related to the identification of the form, structure, and content of constitutions and charters of the subjects of the Russian Federation, those qualities that distinguish this form of law from other forms of law as legal regulators of constitutional, statutory public relations.

The subjects of constitutional proceedings are special bodies and persons participating in constitutional proceedings, possessing, by virtue of the law, subjective procedural rights and duties and exercising them in 
Elena V. Vinogradova, Ekaterina S. Ganicheva, Kasa Ilda, Badma V. Sangadzhiev y Natella A. Sinyaeva

the course of constitutional proceedings. The subject of constitutional legal proceedings is a state body, an official, an individual, or a legal entity. Each subject of constitutional legal proceedings has its procedural status, i.e. a set of procedural powers defined by law (Salikov, 2014).

The ultimate goal of doctrinal understanding of the constitutions and statutes of constituent entities of the Russian Federation is the definition of the concept, legal nature, main content, i.e. the subject of constitutional, statutory regulation, as well as identification of the patterns of the emergence, functioning, and development of constitutions and charters of the constituent entities of the Russian Federation as a source and form of constitutional law in the context of the concepts of socio-political, statelegal, and axiological conditionality and the implementation of the principle of federalism and the tasks of regional development. Legal theorists say that today the rule of law is not built in any country in the world, because this process requires a huge period of stable and systematic building up of relations between society and the state. In our opinion, Canada is the closest country to the rule of law today, as it is a country where they managed to create a legal system in which many subcultures of society are preserved to the maximum extent, including language, traditions, style, and way of life, as well as the quality of life itself.

\section{Discussion}

We will consider the legal process (related to the concept and understanding of the legal nature of constitutional proceedings and the legal status of the Constitutional Court) as a dynamic legal phenomenon, a form of legal activity within the framework of both a jurisdictional (judicial) process and a non-jurisdictional process that is not carried out within the framework of a court hearing. There are other classifications of the legal process, but we will not disclose them in this article. Since we are talking about the legal process as an activity in the aspect of explaining the legal nature of the Constitutional Court, it means that this activity must be organized in a certain way. The basis of this activity should be either substantive or procedural rules of law, as well as the principles of law.

We are interested in the functional approach to the principles of law concerning the legal nature of the Constitutional Court, their practical significance related to the regulation of public relations. For example, V.M. Gorshenev, when defining the principles of procedural activity, writes that they serve as a kind of reference marks, pointers, the observance of which ensures the normal and uniform implementation of traditional and non-traditional legal processes. Since we are talking about the legal process as a theoretical category that combines various types of processes and has practical significance, it is necessary to identify the principles that will be basic for the legal process and will characterize it as a 
specific legal phenomenon. According to A.V. Yurkovskii (2013), the system of representations about the general democratic, generally civilized political and legal values of an organized society, as well as the emergence of this category in Western civilization as a result of constitutional revolutions, should be attributed to the constituent elements of the concept of constitutionalism.

\section{Conclusion}

A special feature of the Federal Constitutional Law No. 1-FCL of July 21, 1994 "On the Constitutional Court of the Russian Federation" is that it combines both material and procedural regulation of the activities of the Constitutional Court of the Russian Federation. For this reason, as well as due to the absence of the Constitutional Court of the Russian Federation of instance relations with any other courts, the procedural part of the Law on the Constitutional Court has a relatively small volume and a simpler structure than the procedural codes. However, the issues of examination in constitutional proceedings remain poorly studied in comparison with similar problems of civil, criminal, and other types of proceedings (Luchin and Doronina, 1999: 111). In particular, the Law on the Constitutional Court of the Russian Federation regulates the issues of evidence and proof in constitutional proceedings in an extremely fragmentary manner. Several fundamental issues arising in connection with the examination are resolved in the Law on the Constitutional Court in a completely different way than in other laws regulating judicial activity. According to Article 52 of the Law on the Constitutional Court, experts are participants in the process - along with the parties, their representatives, witnesses, and interpreters (Grishina, 2006).

The fundamental principle of the legal process is the principle of legality - this principle speaks of the priority of the law and the norms of law applicable to a particular case, expressed in the equality of all under the law. Regardless of whether we are at the stage of the process - at the stage of negotiations, the conclusion of a contract, pre-trial settlement of a dispute, or directly in court, we are primarily guided by the current norms of law in our activities.

The principle of objectivity says that a specific legal case should be resolved based on the actual circumstances of the case, considering the rights and obligations assumed by the parties (rights, obligations, distribution of the burden of proof, presentation of evidence).

The principle of continuity - this principle says that as an activity, the legal process must be continuous and necessarily lead to a specific result.

The principle of accessibility - this principle says that the parties to a particular activity should be able to exercise their rights and apply to 
Elena V. Vinogradova, Ekaterina S. Ganicheva, Kasa Ilda, Badma V. Sangadzhiev y Natella A. Sinyaeva

the court or state bodies to resolve any legal issue or choose alternative methods.

Adversarial principle - this principle is mainly characteristic of the judicial process, but it is often used in resolving a dispute or legal conflict in the framework of an alternative mediation procedure when the parties can choose a mediator or choose a panel of arbitrators in the framework of arbitration proceedings.

The principle of procedural and commercial economy tells us that specific procedural actions should be carried out in a certain allotted period and covered by certain material costs. The principle of objective truth - this principle says that the truth is the main goal of the legal process, and its objectivity is achieved by paying close attention to the actual circumstances of the case, providing evidence of their correct legal assessment with registration in the relevant normative legal act with references to specific norms of law.

The doctrine of a normative legal act as a source of constitutional law is based on the postulate of the dominant position of this source as a form of law. Any state is characterized by a hierarchically structured system of normative legal acts, the supreme position in which is occupied by the constitution. A federal state is characterized by a constitutional system consisting of a federal constitution and constitutions of the constituent parts of the federation. Accordingly, the federal structure of modern Russia determines the existence of two types of constitutional acts - the federal constitution and constitutions and charters of the subjects of the Russian Federation.

\section{Recommendations}

Constitutional law and constitutional-legal regulation have evolved, but constitutional law has always regulated economic relations, although at present such regulation is becoming "more detailed and branched". This has affected not only the content of modern constitutions but also the content of constitutional law as a science, in particular, served as the basis for the emergence and development in legal science of the concepts of "economic constitution" and "constitutional economy". The first concept has a broader application and involves considering quantitative indicators. The second concept is widespread in Western European legal thought, including in Russia, and is based on the analysis of qualitative indicators. These concepts are not opposed to each other, they build scientific ideas "about the existence of several general principles and norms of a constitutional nature that regulate the foundations of economic relations". 
The doctrine of normative legal acts that occupy a supreme position in the legal system is aimed at identifying a certain set of characteristics that reveal both common with other normative legal acts and their special significance. It seems that in the context of the doctrine of a normative legal act as a source and form of constitutional law, the study of the fundamental characteristics that reveal its features is of theoretical and scientificpractical importance. The first characteristic concerns the predestination of the occurrence, the objective necessity, and conditionality of a normative legal act. It is this characteristic that reflects the quality of a normative legal act as a source of law. In this context, it is important to substantiate the genesis of the origin, the concept, and essence, the legal nature of a normative legal act as a source and form of law. The legal nature, in turn, is revealed through such key categories as the properties and functions of a normative legal act. The second characteristic is aimed at revealing the distinctive features and place of a normative legal act in the system of other normative legal acts. In this sense, its characteristics as a form of law are revealed.

The constitutional and legal regulation of the relations under consideration is based on the balance of state, public, and personal interests since the construction of the legislative system should be based on the balance of interests of various subjects of the economic system of society. It is necessary to establish constitutional principles that, despite a certain binary nature, could be built into a logical system of economic relations. The analysis of the constitutional regulation evolution in various countries, including Russia, allows concluding that the constitutional regulation of economic relations is becoming more and more detailed over time. Thus, if attention was mainly paid to securing the right of property and guarantees of its protection in the first formal constitutions and to securing for the legislative body the right of exclusive rights to the emission of money and some other actions in the sphere of the economy, then later many constitutions began to contain special chapters on economic system or even more specific cases of manifestations of economic relations, for example, the chapter on public finance (Andreeva, 2008).

\section{Acknowledgements}

This paper was supported by the RUDN University Strategic Academic Leadership Program. 
Elena V. Vinogradova, Ekaterina S. Ganicheva, Kasa Ilda, Badma V. Sangadzhiev y Natella A. Sinyaeva

\section{Bibliographic References}

ALEKSEEV, Sergei Sergeevich. 1994. State and law. Initial course. Yuridicheskaya literatura. Moscow, Russia.

ANDREEVA, G.N. 2008. "The concept of «economic constitution»: past and present" In: Concept of «economic constitution»: Modern research: collection of scientific papers. Series "State and law". ISISS RAS. Moscow, Russia.

ERSHOV, Valentin Valentinovich. 2018. Legal and individual regulation of public relations. RGUP. Moscow, Russia.

GORSHENEV, Viktor Mikhailovich. 1985. Legal process theory. Yuridicheskaya literatura. Moscow, Russia.

GRISHINA, Ekaterina Pavlovna. 2006. "Special knowledge as the main feature of knowledgeable persons" In: Pravo i politika. No. 7, pp. 5-14.

KOZLOVA, Ekaterina Ivanovna; KUTAFIN, Oleg Emelyanovich. 2012. Constitutional law of Russia: a textbook for students of higher educational institutions studying in the specialty "Jurisprudence". Prospect. Moscow, Russia.

LUCHIN, Victor Osipovich; DORONINA, Olga Nikolaevna. 1999. Citizens' Complaints to the Constitutional Court of the Russian Federation. Zakon i pravo: YUNITI. Moscow, Russia.

SALIKOV, Marat Sabiryanovich. 2014. Constitutional litigation: textbook. Infra-M. Moscow, Russia.

VASILEV, Anatoly Vasilievich. 2008. Sources and form of law" as a scientific category. In: Sources of law: problems of theory and practice: Collection of scientific articles based on the materials of the international scientific and practical conference, May 22-25, 2007. RAP. Moscow, Russia.

VITRUK, Nikolay Vasilievich. 2013. Constitutional justice. Judicialconstitutional law and process: textbook. INFRA-M. Moscow, Russia.

YURKOVSKII, Alexey Vladimirovich. 2013. "Constitutionalism: a systematic approach to the formation of a universal political and legal category" In: Sibirskii yuridicheskii vestnik. Vol. 3, No. 62, pp. 20-28. 
Vol. 39 N $^{\circ} 69$

Esta revista fue editada en formato digital y publicada en julio de 2021, por el Fondo Editorial Serbiluz, Universidad del Zulia. Maracaibo-Venezuela 